\title{
Deterministic economic analysis of feedlot Red Angus young steers: slaughter weights and bonus
}

\author{
Análise econômica determinística do confinamento de novilhos Red Angus superjovens: \\ pesos de abate e bonificações \\ Paulo Santana Pacheco ${ }^{I}$ Fabiano Nunes Vaz ${ }^{\text {II }}$ João Restle ${ }^{\text {III }}$ Mozer Manetti de Ávila ${ }^{\text {IV }}$

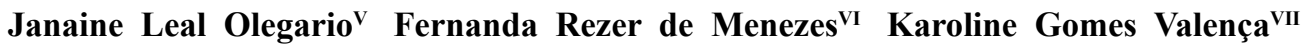 \\ Daniel Batista Lemes ${ }^{\text {VII }}$ Fabiano Vargas de Vargas ${ }^{\mathrm{VII}}$
}

\begin{abstract}
The joint analysis of indicators of the investment project is very relevant in making decisions, resulting in more consistent information regarding risk assessment and its confrontation with the possibility of return. This research aimed to evaluate the economic feasibility of Red Angus young steers finished in feedlot, slaughtered at 340,373, 396 or $430 \mathrm{~kg}$ with use of various financial indicators, marketed with or without bonus. The purchase of feeder cattle and feeding were variable costs with a higher share in the total cost. In the analysis with bonus, the regression analysis to gross margin, net margin, net present value, benefit:cost index and additional return on investment showed quadratic behavior, with the point of maximum at $406 \mathrm{~kg}$ ( $R \$ 185.17), 406 \mathrm{~kg}(R \$ 161.76), 393 \mathrm{~kg}(R \$ 128.29), 392 \mathrm{~kg}(1.12)$, $392 \mathrm{~kg}(11.98 \%)$, respectively. In the analysis without bonus, gross margin and net margin showed a quadratic response $346 \mathrm{~kg}$, with $R \$ 110.31$ and $R \$ 86.90$, respectively), while for the other indicators, there was a linear reduction as an increase in slaughter weight.
\end{abstract}

Key words: investment analysis, risk analysis, beef cattle, ideal slaughter weight, termination system.

\section{RESUMO}

A análise conjunta de indicadores do projeto de investimento é muito relevante na tomada de decisões, resultando em informações mais consistentes da avaliação do risco e seu confronto com a possibilidade de retorno. Este trabalho teve como objetivo avaliar a viabilidade econômica da terminação de novilhos Red Angus superjovens em confinamento, abatidos com 340, 373, 396 ou 430kg, com uso de diversos indicadores financeiros, comercializados com ou sem bonificação. A compra dos bois magros e a dieta foram os custos variáveis com maior participação no custo total. Na análise com bonificação, a análise de regressão para margem bruta, margem líquida, valor presente líquido, índice benefício:custo e retorno adicional sobre o investimento demonstrou comportamento quadrático, com ponto de máxima aos 406kg ( $R \$ 185,17), 406 \mathrm{~kg}$ ( $R \$ 161,76), 393 \mathrm{~kg}$ (R\$ 128,29), $392 \mathrm{~kg}(1,12), 392 \mathrm{~kg}(11,98 \%)$, respectivamente. $\mathrm{Na}$ análise sem bonificação, margem bruta e margem líquida apresentaram comportamento quadrático $(346 \mathrm{~kg}$, sendo de $R \$ 110,31$ e $R \$ 86,90$, respectivamente), enquanto que, para os demais indicadores, houve redução linear, conforme aumento no peso de abate.

Palavras-chave: análise de investimentos, análise de risco, bovinos de corte, peso ideal de abate, sistema de terminação.

\section{INTRODUCTION}

In Brazil, the number of confined animals has increased in recent years (ANUALPEC, 2013), being considered the confinement technology that allows the intensification of beef production per animal and per area mainly. From the technical point of view, the confinement presents well documented advantages, however, under the economic aspect, the monitoring of costs and revenues and more refined assessment of the viability of these investment

'Departamento de Zootecnia, Universidade Federal de Santa Maria (UFSM), 97105-900, Santa Maria, RS, Brasil. E-mail: pacheco.dz.ufsm@hotmail.com. Corresponding author.

"Departamento de Educação Agrícola e Extensão Rural, UFSM, Santa Maria, RS, Brasil.

IIIUniversidade Federal do Tocantins (UFT), Araguaína, TO, Brasil.

IVPrograma de Pós-graduação em Zootecnia, UFSM, Santa Maria, RS, Brasil.

${ }^{\vee}$ Curso Superior de Tecnologia em Agronegócio, UFSM, Santa Maria, RS, Brasil.

${ }^{\mathrm{VI}}$ Curso de Estatística, UFSM, Santa Maria, RS, Brasil.

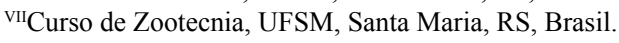


projects are needed. In this context, determine how approach and / or analyze a termination system economically has practical application of great value and can be adapted according to the particular reality of each farm.

Aiming to conquer the domestic market niches that best remunerate the end product, demanding in relation to carcass quality and meat, it is common practice to use marketing by associations of cattle breeds. In this aspect, the Angus breed has been outstanding at national level, implementing a bonus program in partnership with industry, with the possibility of increasing the amount paid for the carcass of up to $10 \%$ (ABA, 2014). This program takes into account the weight and carcass finishing, slaughter age and breed standard. The higher slaughter weight, the greater the bonus, leading to reflect on the possibility of extending the time to feed and / or enhance the nutritional level of the diet in order to reach this goal. However, it is known the consequent increase in operating expenses, which many authors (MISSIO et al., 2009; LOPES et al., 2013) reported that disregarding the cost of acquisition of feeder cattle, the feed costs represent more than $70 \%$ of the variable costs and can put the system in a delicate situation when analyzing the cost-benefit.

Thus, the joint analysis of indicators of the investment project is very relevant in decision making. SOUZA \& CLEMENTE (2009) suggests the joint analysis of several economic indicators, resulting in more consistent information regarding risk assessment and its confrontation with the possibility of profit. This approach was implemented and discussed in agronomic studies (SOUZA et al., 2010), however, still little explored in the field of animal production.

This study aimed to evaluate the economic viability, under the deterministic point of view, of the feedlot finished steers Aberdeen Angus variety Red, slaughtered at different weights using or not the bonus of quality programs in slaughterhouse industry, considering various financial indicators.

\section{MATERIALS AND METHODS}

The experiment was conducted in the Department of Animal Science, Federal University of Santa Maria, Rio Grande do Sul state, Brazil. Economic viability of the feedlot was assessed via deterministic analysis. Were used steers Aberdeen Angus, Red variety, fed to reach slaughter weights of $340,370,400$ or $430 \mathrm{~kg}$, with real weights obtained from $340,373,396$ and $430 \mathrm{~kg}$, respectively.
Were used 24 animals, taken at random from the same herd, with an initial average weight of $189.1 \pm 1.78 \mathrm{~kg}$ and average initial age of eight months. The confinement began in July, where the animals were fed ad libitum a diet with $13.11 \%$ crude protein and $2.7 \mathrm{Mcal}$ digestible energy $\mathrm{kg}^{-1}$ dry matter (DM). The ingredients of the concentrate were soybean bran (24.79\%), soybean hulls (52.62), rice bran (20.00), minerals (2.54) and monensin (0.05\%).

Slaughter weights were considered mutually excluding investment projects. To estimate the costs, revenues and financial indicators (estimated per animal), mean values practiced in Rio Grande do Sul in the years 2004 to 2012 were used, for 2012 deflated by the IGP-DI index of the Fundação Getúlio Vargas, from the following sources: CONAB - National Supply Company, IEA - Institute of Agricultural Economics of São Paulo, EMATER / RS-ASCAR and ANUALPEC - Brazilian Yearbook of Livestock.

For classification of items of costs, revenues and calculation of financial indicators, methodologies proposed by RESENDE FILHO et al., (2001), LAPPONI (2007) and SOUZA \& CLEMENTE (2009) were used. Were used the cost items according to PACHECO et al. (2014). For definition of subsidies it was used the criterion of ABA (2014), which takes into account criteria such as age, weight and carcass finishing. The performance items of animals and bonus, according to slaughter weight contained in table 1.

The facility costs were estimated for static capacity of 1000 animals and lifespan of 10 years. Depreciation (plant, machinery, implements and equipment) were calculated for a planning horizon of one year, with an estimated value of US\$ 0.03 animal $^{-1}$ day $^{-1}$. Opportunity costs were calculated considering the minimum rate of attractiveness (TMA) of $0.4868 \%$ per month $(6 \%$ per year). The opportunity cost of capital invested was obtained by the sum of operating expenses (feeder cattle purchase, health control, forage plus concentrate feed, labor, and others) for the period corresponding to the number of months stipulated for each slaughter weight. For the opportunity cost of land (referring only to the area designated for the confinement facility), we considered the possibility at the annual rental equivalent to $3 \%$ of the hectare to agriculture ( R \$ 7,388.30). Was determined for each animal the use of 0.05 ha.

Sanitary control consisted of applying product to control endo and ectoparasites (ivermectin 1\%), analgesic and anti-inflammatory, antibiotic and vaccines 
Table 1 - Means for performance items and bonus, according to slaughter weight.

\begin{tabular}{|c|c|c|c|c|}
\hline \multirow{2}{*}{ Items } & \multirow[b]{2}{*}{340} & \multirow[b]{2}{*}{373} & \multirow[b]{2}{*}{396} & \multirow[b]{2}{*}{430} \\
\hline & & & & \\
\hline Feeding time (days) & 114 & 144 & 168 & 209 \\
\hline Slaughter age (months) & 12 & 13 & 14 & 15 \\
\hline Dry matter intake $\left(\mathrm{kg} \mathrm{day}^{-1}\right)$ & 6.70 & 6.80 & 6.85 & 6.94 \\
\hline Total weight gain $(\mathrm{kg})$ & 150.42 & 182.88 & 206.64 & 240.35 \\
\hline Bonus $(\%)$ & 3 & 7 & 7 & 10 \\
\hline Finished cattle without bonus $\left(\mathrm{R} \$ \mathrm{~kg}^{-1}\right)$ & 3.08 & 3.08 & 3.08 & 3.08 \\
\hline Finished cattle with bonus $\left(\mathrm{R} \$ \mathrm{~kg}^{-1}\right)$ & 3.17 & 3.30 & 3.30 & 3.39 \\
\hline
\end{tabular}

against mouth disease, botulism and clostridiosis all in dosage per animal according to manufacturers' recommendations.

The feed cost was obtained by the product of the total consumption of roughage and concentrate $\left(\mathrm{kg} \mathrm{DM}\right.$ animal ${ }^{-1}$ ) for their respective costs $\mathrm{kg}^{-1} \mathrm{DM}$.

For cost estimates with labor, considered the need for 1 man 300 animals $^{-1}$ to day labourer (R\$ 17.84 man day $^{-1}$ ) and three minimum wages month $^{-1} 1,000$ animals $^{-1}$ for the technical assistance (national minimum wage of $\mathrm{R} \$ 520.11$ ). Two months were added to the feeding period for preparation/ maintenance of facilities and other activities.

Maintenance of facilities, machinery, implements and equipment, fuel, electricity, freight and taxes were estimated for the equivalent of $4 \%$ of operating expenses mentioned above to estimate the opportunity cost of invested capital, being called other operating expenses. The equations used to estimate the costs, revenues and financial indicators are presented in PACHECO et al. (2012).

To estimate the financial indicators NPV, IB:C, ROIA and IRR, cash flows planning horizon of one year have been prepared, as suggested by RESENDE et al. (2001). For purposes of currency conversion R $\$ 1.00=$ US\$ 0.54 .

The data were submitted to polynomial regression (5\% of significance level) according to the following model: $\mathrm{y}_{\mathrm{ij}}=\mathrm{b}_{0}+\mathrm{b}_{1} \mathrm{x}_{\mathrm{i}}+\mathrm{b}_{2} \mathrm{x}^{2}{ }_{\mathrm{i}}+\mathrm{e}_{\mathrm{ij}}$, were: $\mathrm{y}_{\mathrm{ij}}=$ dependent variable; $\mathrm{b}_{0}, \mathrm{~b}_{1}, \mathrm{~b}_{2}=$ parameters of regression; $\mathrm{x}_{\mathrm{i}}=$ slaughter weight and $\mathrm{e}_{\mathrm{ij}}=$ random error.

\section{RESULTS AND DISCUSSION}

The detailing of the total cost (Table 2) demonstrates the expressive participation of variable costs, and these, purchase of the feeder cattle followed by food (forage and concentrate) were the items most relevant. We note that the increase in slaughter weight resulted in change this relationship, ie, from $396 \mathrm{~kg}$ of food was greater relevance ( $R$ \$ 541.69) in relation to cost of purchase of the feeder animal ( $\mathrm{R} \$ 483.83)$.

The behavior of the estimated costs in this study are consistent with other studies involving the termination of beef cattle feedlot (MISSIO et al., 2009; LOPES et al., 2013; PACHECO et al., 2014). These results demonstrate the importance of planning the marketing season of animals, and the purchase of raw materials for making the diet as strategies that can result in reduction in the total cost and maximization of total revenues, providing this way, the economic success of the activity. Furthermore, LOPES et al. (2007) and LOPES et al. (2013) comment on the possibility of reduction in depreciation values with increasing cycles of fattening and static capacity of confinement facilities.

Another important aspect is the marketing strategy of animals, characterized in this study by the bonus. Comparing the regression coefficients (R\$ 4.15 vs $\mathrm{R} \$ 3.08 \mathrm{~kg}^{-1}$ slaughter weight), the increase in total revenue with a bonus was $35 \%$ higher than without bonus as increased slaughter weight. The increase in total revenue with bonus has exceeded even the increase in total cost $\left(\mathrm{R} \$ 4.07 \mathrm{~kg}^{-1}\right.$ slaughter weight), demonstrating the advantage of the economic standpoint the investment in changes/ improvements in beef cattle production systems to participate of awards programs offered by breed associations and slaughterhouses industry. Although slaughter weights evaluated in the present study are lower than the average practiced in confinements of Brazil (close to 500 pounds, MILLEN et al., 2009), is common in the southern region of the country the marketing of beef cattle with carcass weights above 
Table 2 - Means for components of costs and revenues, estimated per animal, according to slaughter weight.

\begin{tabular}{|c|c|c|c|c|}
\hline \multirow[t]{2}{*}{ Items } & \multirow[b]{2}{*}{340} & \multirow[b]{2}{*}{373} & \multirow[b]{2}{*}{396} & \multirow[b]{2}{*}{430} \\
\hline & & & & \\
\hline Fixed costs $(\mathrm{CF})(\mathrm{R} \$)$ & 32.94 & 32.94 & 32.94 & 32.94 \\
\hline Depreciation (R\$) & 23.41 & 23.41 & 23.41 & 23.41 \\
\hline Opportunity (R\$) & 9.54 & 9.54 & 9.54 & 9.54 \\
\hline Variable costs $(\mathrm{CV})(\mathrm{R} \$)^{1}$ & 961.34 & 1076.10 & 1168.66 & 1328.31 \\
\hline Purchase of feeder cattle (R\$) & 483.83 & 483.83 & 483.83 & 483.83 \\
\hline Health control $(\mathrm{R} \$)$ & 13.69 & 13.69 & 13.69 & 13.69 \\
\hline Feeding roughage $(\mathrm{R} \$)^{2}$ & 155.08 & 195.89 & 228.54 & 284.32 \\
\hline Feeding concentrate $(\mathrm{R} \$)^{3}$ & 212.50 & 268.42 & 313.15 & 389.58 \\
\hline Labor $(\mathrm{R} \$)^{4}$ & 33.89 & 39.73 & 44.40 & 52.39 \\
\hline Other operating expenses $(\mathrm{R} \$)^{5}$ & 35.96 & 40.06 & 43.34 & 48.95 \\
\hline Opportunity of invested capital $(\mathrm{R} \$)^{6}$ & 26.40 & 34.48 & 41.69 & 55.56 \\
\hline Effective operational cost $(\mathrm{COE})(\mathrm{R} \$)^{7}$ & 934.94 & 1041.62 & 1126.96 & 1272.75 \\
\hline Total operational cost $(\mathrm{COT})(\mathrm{R} \$)^{8}$ & 958.35 & 1065.03 & 1150.37 & 1296.16 \\
\hline Total cost $(\mathrm{CF}+\mathrm{CV})(\mathrm{R} \$)^{9}$ & 994.28 & 1109.04 & 1201.60 & 1361.25 \\
\hline Cost/kg weight gain $(\mathrm{R} \$ / \mathrm{kg})$ & 3.39 & 3.50 & 3.45 & 3.39 \\
\hline Cost/@(R\$/@) & 101.76 & 105.04 & 103.37 & 101.57 \\
\hline Revenue without bonus $(\mathrm{R} \$)^{10}$ & 1047.20 & 1148.84 & 1218.76 & 1325.32 \\
\hline Revenue with bonus $(\mathrm{R} \$)^{11}$ & 1078.62 & 1229.26 & 1304.07 & 1457.86 \\
\hline
\end{tabular}

${ }^{1} \mathrm{y}_{\mathrm{i}}=-431.66+4.06 \mathrm{PA} ; \mathrm{R}^{2}=0.9949 ; \mathrm{P}=0.0026 .{ }^{2} \mathrm{y}_{\mathrm{i}}=-335.32+1.43 \mathrm{PA}_{\mathrm{i}} ; \mathrm{R}^{2}=0.9955 ; \mathrm{P}=0.0023 .{ }^{3} \mathrm{y}_{\mathrm{i}}=-459.42+1.96 \mathrm{PA} ; \mathrm{R}^{2}=0.9955 ; \mathrm{P}=0.0023$.

${ }_{7}^{4} \mathrm{y}_{\mathrm{i}}=-36.31+0.20 \mathrm{PA}_{\mathrm{i}} ; \mathrm{R}^{2}=0.9955 ; \mathrm{P}=0.0023 .{ }^{5} \mathrm{y}_{\mathrm{i}}=-13.33+0.14 \mathrm{PA}_{\mathrm{i}} ; \mathrm{R}^{2}=0.9955 ; \mathrm{P}=0.0023 .{ }^{6} \mathrm{y}_{\mathrm{i}}=-84.78+0.32 \mathrm{PA}_{\mathrm{i}} ; \mathrm{R}^{2}=0.9849 ; \mathrm{P}=0.0076$

${ }_{7}^{7} \mathrm{y}_{\mathrm{i}}=-346.87+3.75 \mathrm{PA}_{\mathrm{i}} ; \mathrm{R}^{2}=0.9955 ; \mathrm{P}=0.0022 .{ }^{8} \mathrm{y}_{\mathrm{i}}=-323.46+3.75 \mathrm{PA}_{\mathrm{i}} ; \mathrm{R}^{2}=0.9955 ; \mathrm{P}=0.0022 .{ }^{9} \mathrm{y}_{\mathrm{i}}=-398.72+4.07 \mathrm{PA} i \mathrm{R}^{2}=0.9949 ; \mathrm{P}=0.0026$.

${ }^{10} \mathrm{y}_{\mathrm{i}}=0.012+3.08 \mathrm{PA}_{\mathrm{i}} ; \mathrm{R}^{2}=0.9999 ; \mathrm{P}=0.0001 .{ }^{11} \mathrm{y}_{\mathrm{i}}=-327.61+4.15 \mathrm{PA}_{\mathrm{i}} ; \mathrm{R}^{2}=0.9973 ; \mathrm{P}=0.0013$.

$180 \mathrm{~kg}$ (approximately $340 \mathrm{~kg}$ of slaughter weight) derived from intensive production systems, such as the termination of young steers.

In relation to economic indicators, SOUZA $\&$ CLEMENTE (2009) present the advantages of the use thereof together, characterized by the deepening of risk assessment and its confrontation with the possibility of return of an investment project. Moreover, results in more consistent information than the separate use of each or a subset of them. According literature review in animal production, has been little explored the economic evaluation of production systems and / or technologies using as decision criteria the evaluation of various economic indicators.

According to regression analysis (Figure 1), the estimates of economic indicators showed better results when was considered the bonus. For gross margin - GM, net margin - ML and net present value - NPV, slaughter weights of 406, 406 and $393 \mathrm{~kg}$, respectively, were those with the highest values (maximum point) ( $\mathrm{R} \$ 185.17$; $\mathrm{R} \$ 161.76$ and $\mathrm{R} \$$ 128.29, respectively).
In the analysis without bonus, the largest estimates for GM and ML occurred to lighter weights $(346 \mathrm{~kg})$, being $\mathrm{R} \$ 110.31$ and $\mathrm{R} \$$ 86.90 , respectively. While for NPV, the behavior decreased linearly as increased slaughter weight. The interpretation of economic indicators is essential to the use of the estimated results of the management standpoint. SIMÕES et al. (2007) commented that the positive GM indicates the possibility of economic viability in the short term, because it covers effective operating cost (direct payments). Positive values for the ML demonstrate economic viability in the medium term, with the possibility of staying in the long term, because cover effective operating costs and depreciation. According LAPPONI (2007), NPV of zero indicates that recovers the initial investment cost and also pays this cost if it had been applied to the minimum rate of attractiveness. In the present study, the only possibility of economic infeasibility occurred for greater slaughter weight, considering the NPV indicator. These results demonstrate that not always the decision-making coincide for all 


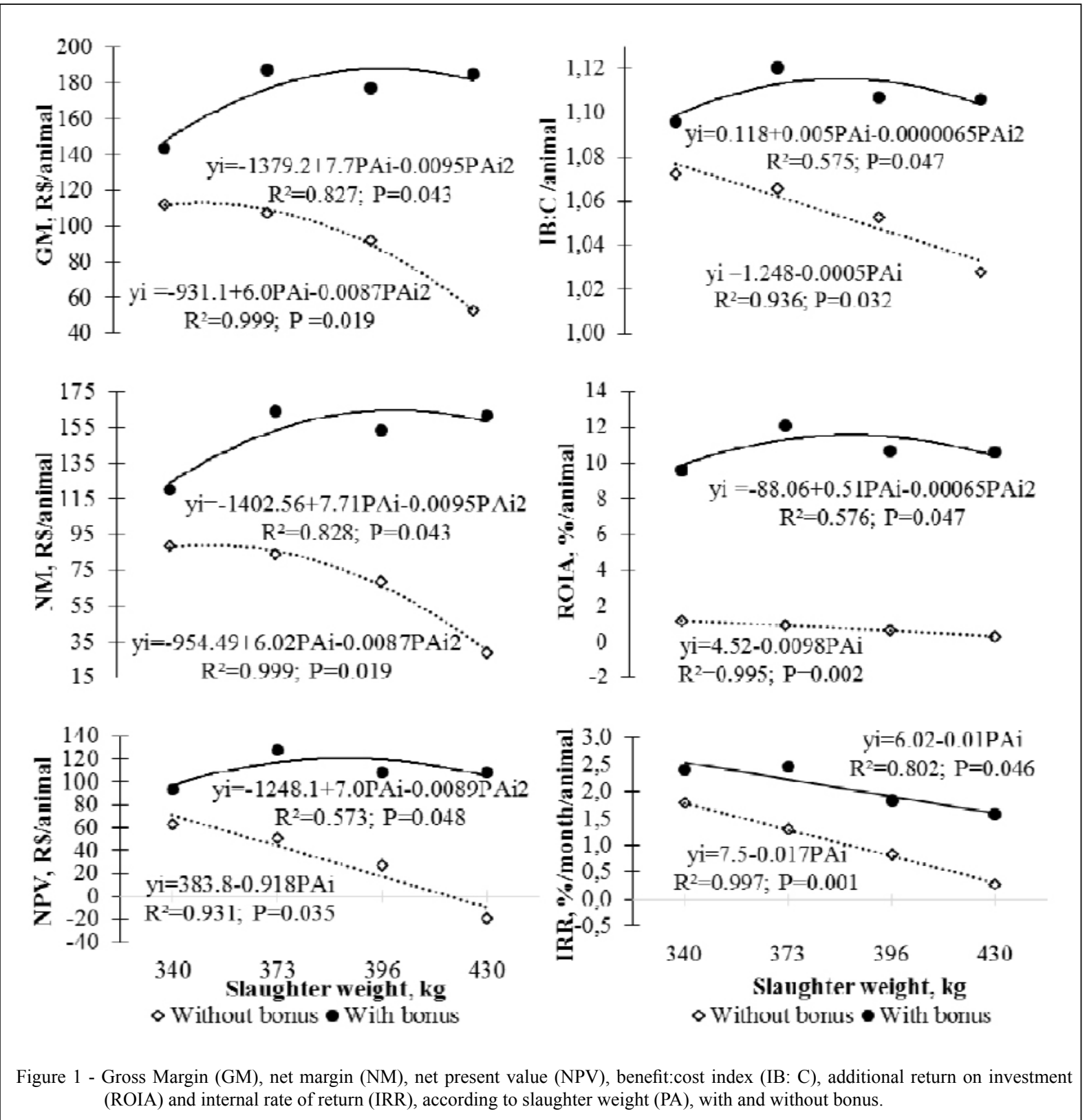

estimated economic indicators. SIMÕES et al. (2007) compared the phases of cattle production system (breeding, post-weaning and fattening) and found that for the finishing phase gross margin was positive, while net margin and profit were negative, and concluded that investment in this system was less attractive than other activity with the return on capital invested at $6 \%$ per year.

In analysis with bonus, benefit: cost index - IB:C and additional return on investment ROIA showed a quadratic response with increasing slaughter weight, with maximum estimates of these indicators for the slaughter weight of $392 \mathrm{~kg}$ ( 1.12 and $11.98 \%$, respectively). While for the estimates without bonus, the response was linear decreasing. IB: $\mathrm{C}$ represents the ratio between the present value of the flow of benefits (revenues) and the present value of the flow of investments (costs) (LAPPONI, 2007) being interpreted as the benefit after deducting the revenue that would be obtained if each R\$ 1.00 had been applied in the minimum rate of attractiveness. On the study of MELLO et 
al. (2009) there was significant reduction in IB:C with the increase in slaughter weight. Regarding ROIA, SOUZA \& CLEMENTE (2009) state that this economic indicator is the wealth generated by the investment, ie, that accrue besides the application of the capital in the minimum rate of attractiveness.

For internal rate of return - IRR, both with and without correlation analysis, there was a linear decrease with the increase in slaughter weight. However, only for the slaughter weight of $430 \mathrm{~kg}$ without bonus IRR $(0.2876 \%$ per month $)$ was less than the minimum rate of attractiveness $(0.4868 \%$ per month). In one of the few studies involving the use of financial indicators in decision-making on investment projects involving the feedlot beef cattle, PACHECO et al. (2014) showed economic infeasibility of this system with lower returns and higher risk increased as the level of concentrate in the diet. There was agreement between the values of the indicators used, demonstrating its relevance in decision making. The authors estimated $\mathrm{R} \$-119.77$ to gross margin, $\mathrm{R} \$-129.63$ to net margin, $\mathrm{R} \$-144.01$ to net present value, 0.8994 for benefit:cost index, $-10.06 \%$ for additional return on investment and $-3.84 \%$ internal rate of return.

\section{CONCLUSION}

The components of total cost with greater relevance were the variable costs purchase of the feeder cattle and feeding. The marketing of animals with the bonus represented an expressive advantage compared to that without bonus, for all estimated financial indicators. Regression analysis to the financial indicators showed that the slaughter weights light to intermediaries represented the best options for finishing young steers in feedlot.

\section{ETHICS COMITTE AND BIOSECURITY}

We authors of the article entitled "Deterministic economic analysis of feedlot Red Angus young steers: slaughter weights and bonus" declare for the proper purposes, the project that gave rise to the same data was not submitted for evaluation to the Ethics Committee of the "University Federal de Santa Maria" but we are aware of the content of the resolutions of the National Council for Control Experimentation Animal - CONCEA <http:// www.met.gov.br/index.php/content/view/310553.html> case involving animals.

Thus, the authors assume full responsibility for the presented data and are available for possible questioning, should they be required by the competent bodies.

\section{REFERENCES}

ABA (ASSOCIAÇÃO BRASILEIRA DE ANGUS), Porto Alegre, RS. Available from: $<$ http://angus.org.br/carne-angus-2/tabela-depremiacoes/>. Acessed: Jan. 18, 2014.

LAPPONI, J.C. Projetos de investimento na empresa. Rio de Janeiro: Elsevier, 2007. 488p.

LOPES, M.A. et al. Análise econômica da terminação de bovinos de corte em confinamentos no estado de Minas Gerais: estudo de caso. Revista Ceres, Viçosa, v.60, n.4, p.465473, 2013. Available from: <http://www.scielo.br/pdf/rceres/ v60n4/04.pdf $>$. Acessed: Apr. 15, 2014. doi: 10.1590/S0034737 X2013000400004.

LOPES, M.A. et al. Efeito da escala de produção na rentabilidade da terminação de bovinos de corte em confinamento. Revista Ciência e Agrotecnologia, Lavras, v.31, n.1, p.212-217, 2007. Available from: <http://www.scielo.br/pdf/cagro/v31n1/ v31n1a31.pdf $>$. Accessed: Apr. 13, 2014. doi: 10.1590/S141370542007000100031

MELLO, R. et al. Bio-economicity of the finishing phase on feedlot of crossbred young bulls slaughtered at different body weights. Revista Brasileira de Zootecnia, Viçosa, v.38, n.1, p.109-121, 2009. Available from: <http://www.scielo.br/scielo. php?script $=$ sci_arttext\&pid $=$ S 1516-35982009000100015>. Accessed: Apr. 01, 2014. doi: 10.1590/S151635982009000100015 .

MILLEN, D.D. et al. A snapshot of management practices and nutritional recommendations used by feedlot nutritionists in Brazil. Journal of Animal Science, Champaign, v.87, p.34273439, 2009. Available from: <http:/www.ncbi.nlm.nih.gov/ pubmed/19574564>. Accessed: Apr. 01, 2014. doi: 10.2527/ jas.2009-1880

MISSIO, R.L. et al. Desempenho e avaliação econômica da terminação de tourinhos em confinamento alimentados com diferentes níveis de concentrado na dieta. Revista Brasileira de Zootecnia, Viçosa, v.38, n.7, p.1309-1316, 2009. Available from: <http://www.ncbi.nlm.nih.gov/ pubmed/19574564>. Accessed: Apr. 01, 2014. doi: 10.1590/ S1516-35982009000700021.

PACHECO, P.S. et al. Análise econômica da terminação de novilhos em confinamento recebendo diferentes proporções de cana-deaçúcar e concentrado. Semina: Ciências Agrárias, Londrina, v.35, n.2, p.999-1012, 2014. Available from: <http://www.uel.br/ revistas/uel/index.php/semagrarias/article/view/12545/pdf 300>. Accessed: Apr. 15, 2014. doi: 10.5433/1679-0359.2014v35n 2 p999.

PACHECO, P.S. et al. Indicadores econômicos da terminação em confinamento de novilhos jovens abatidos com diferentes pesos. In: CONGRESSO DA SOCIEDADE BRASILEIRA DE ECONOMIA, ADMINISTRAÇÃO E SOCIOLOGIA RURAL, 50, Agricultura e Desenvolvimento Rural com Sustentabilidade, 2012, Vitória, ES. Anais... Vitória: SOBER, 2012. (CD-ROM). p.01-14.

RESENDE FILHO, M.A. et al. Sistemas de terminação em confinamento: perspectivas para dinamização da cadeia produtiva da carne bovina em Minas Gerais. Revista Brasileira de Economia, Rio de Janeiro, v.55, n.1, p.107-131, 2001. Available 
from: <http://www.scielo.br/pdf/rbe/v55n1/a05v55n1.pdf >. Accessed: Apr. 14, 2014.

SIMÕES, A.R.P. et al. Avaliação econômica comparativa de sistemas de produção de gado de corte sob condições de risco no Mato Grosso do Sul. Revista de Economia e Agronegócio, Viçosa, v.5, n.1, p.51-72, 2007. Available from: <http://www. economia-aplicada.ufv.br/revista/pdf/2007/Volume_n3_07.pdf $>$. Accessed: Apr. 14, 2014.
SOUZA, A.; CLEMENTE, A. Decisões financeiras e análise de investimentos. 6.ed. São Paulo: Atlas, 2009. 186p.

SOUZA, A. et al. Custos de produção, expectativas de retorno e de risco para o agronegócio do milho na região do Planalto Norte - Catarinense / Brasil. Custos e @gronegócio on line, Recife, v.6, n.1, p.140-159, 2010. Available from: <http://www. custoseagronegocioonline.com.br/numero1v6/Custos $\% 20 \mathrm{de} \% 20$ producao.pdf>. Accessed: Apr. 14, 2014 